\title{
Systemic Racism: Refugee, Resettlement, and Education Policy in New Zealand
}

\author{
Louise Humpage
}

\begin{abstract}
Public policy in New Zealand increasingly makes reference to "inclusion of diversity," "equality," and "equity." Yet refugees resettling in New Zealand continue to experience systemic racism based on the application of ostensibly neutral rules and universal standards to unequal situations. This paper draws attention to the way in which poorly formulated refugee and resettlement policy has resulted in quota refugees being favoured over others and in assumptions that refugees have needs similar to those of general migrants. The way in which such racism has been translated into general policy arenas, such as education, is also explored.
\end{abstract}

\section{Résumé}

De manière croissante, la politique officielle en Nouvelle Zélande fait référence aux notions d' inclusion de la diversité ", d' "égalité » et d' "équité ». Malgré cela, les réfugiés qui se réinstallent en Nouvelle Zélande continuent à pâtir du racisme systémique émanant de l'application de règles et de normes universels qui, quoique neutres en apparence, s'adressent en fait à des situations tout à fait inégales. Cet article éclaire la façon par laquelle une politique d'immigration et de réinstallation mal formulée a donné lieu à du favoritisme au profit des réfugiés des catégories réservées ("quota refugees") et a entretenu des croyances que les besoins des réfugiés sont similaires à ceux d'autres immigrants. Est aussi exploré la manière dont ce racisme s'est trouvé reflété dans des domaines de politique générale, tel celui de l'éducation.

\section{Introduction}

$\mathrm{R}$ efugees resettling in New Zealand come from a diverse range of countries and backgrounds. Yet they share the experience of suffering systemic racism based on the application of ostensibly "neutral" rules and "universal" standards to unequal situations in refugee, resettlement, and education policy. This application has had the real effect of discriminating against refugees, particularly those from non-English-speaking, non-European, and less-educated backgrounds. This paper draws attention to the way in which poorly formulated refugee and resettlement policy has resulted in quota refugees being favoured over others and in assumptions that all categories of refugees have needs similar to those of general migrants, despite considerable research that provides evidence to the contrary.

In addition, the paper highlights how both of these situations have had a domino effect on policy in more general arenas, with education used as an example. Until very recently, education policy also prioritized quota refugees. In failing to account for the pre- and postsettlement characteristics of refugees in policy making, education policy continues to perpetuate the notion that refugees are not different from general migrants. Ironically, poor recognition of refugee student needs in education policy sits alongside aims articulating the "inclusion of diversity," "equality," and "equity."

The paper explores such arguments by outlining refugee and resettlement policy as it relates to all categories of refugees, regardless of age. However, for the sake of brevity, discussion of education policy is limited to refugee students in the compulsory education sector and excludes the (minimal) policy concerning refugee adults. 
Refugees are, of course, a diverse group of people, originating from a variety of national and ethnic backgrounds, as well as socio-economic and educational statuses. Yet in reviewing the difficulties that refugee students face in light of poor policy formulation, examples are provided from research ${ }^{1}$ conducted with Somali students in Christchurch, one of New Zealand's larger cities. Coming from a non-European, non-Christian, nonEnglish-speaking background, in combination with the extended period many have spent in refugee camps, Somali represent a major challenge for resettlement and education services. It is difficult to ascertain whether the Somali experience in Christchurch is representative of refugee students in New Zealand in general. But the Somali experience certainly highlights the potential pitfalls in education policy for refugees, who are increasingly coming from diverse backgrounds that are very different from those of most New Zealanders.

\section{The Faces of Racism}

There are many faces of racism at the individual, institutional, and societal levels. This paper does not focus on individual acts of denial or exclusion against a group based on biological or cultural inferiority. ${ }^{2}$ Nor does it explore the hegemonic processes of societal racism. Rather, it considers the institutional racism embedded within the organizational practices and procedures of New Zealand's social institutions, which either deliberately or inadvertently discriminate against "others." ${ }^{3}$ In particular, central government institutions, such as the immigration, justice, health, and education systems, contain or distribute a variety of resources, both social and economic. Differential access procedures and monoculturalism within an institution often mean that minority groups cannot gain access to these resources, and therefore experience discrimination and disadvantage. This inequality may occur even when people-collectively or as individuals-within the institution are not racist in terms of their attitudes and when the institution itself has adopted policies of biculturalism or multiculturalism, acknowledging and valuing cultural difference. ${ }^{4}$

Fleras and Elliott ${ }^{5}$ note that there are two main forms of institutional racism. The first, systematic racism, involves rules and procedures that directly and deliberately prevent minority groups from full and equal involvement within society. Immigration policy in New Zealand has certainly provided cases of this form of discrimination. For example, in the nineteenth century, only Chinese im- migrants to New Zealand were subject to a poll tax and English proficiency tests. While a ban on New Zealandborn Chinese acquiring citizenship was lifted in 1952, it was not until 1987 that explicit favouritism towards immigrants from Great Britain and Europe was abolished. ${ }^{6}$ There have also been cases of systematic racism in the education system, most notably where Maori, the indigenous peoples of New Zealand, were banned from speaking their own language under the 1877 Education Act.?

However, this paper focuses on systemic racism-the subtle yet powerful form of discrimination entrenched within the rules, organization, norms, goals, and procedures of social institutions. Many New Zealand institutions now articulate philosophies of biculturalism or multiculturalism. Yet the application of ostensibly "neutral" rules and "universal" standards to unequal situations has the real effect of discriminating against some because of their differences. Even when differences are taken into account, customized treatment is expected to fit within an ethnocentric "one size fits all" mentality that reflects a liberal pluralist commitment to a superficial pluralism, rather than taking differences seriously. This form of institutional discrimination is, by definition, unconscious and unintended because of its embeddedness within structures, functions, and processes that are taken for granted. ${ }^{8}$ As discussion highlights, systemic racism is common in the New Zealand's refugee, resettlement, and education policies.

\section{A Neo-Liberal Context}

In making this assertion, particular note has been made of the economic and political context in which recent policy has been made. It is argued that the neo-liberal restructuring of the New Zealand public sector in the $1980 \mathrm{~s}$ and the continuing prevalence of a market-economy philosophy in the 1990s has provided an important contextual background to the systemic racism found in all three policy arenas. ${ }^{9}$ Even the election of a centre-left government $^{10}$ in 1999 has not radically altered the neo-liberal agendas that discriminate against refugees.

Systemic racism existed in immigration, resettlement, and education policy well before the neo-liberal reforms that restructured the New Zealand public sector in the 1980s. While it is difficult to establish a "cause and effect" process, neo-liberal agendas have nevertheless enhanced the systemic racism that refugees resettling in New Zealand have long suffered. For instance, immigration policy has now theoretically eliminated discrimination on grounds of race, national or ethnic origin, colour, sex, 
marital status, religion, or ethical belief." ${ }^{11}$ Yet the new focus on "sustained economic growth" in immigration policy since 1991 implicitly restricts the access of many refugees to resettle in New Zealand. In addition, a neoliberal emphasis on decentralization has entrenched the expectation that resettlement services be provided by a non-governmental organization ( $\mathrm{NGO}$ ) sector that is incompletely funded by the government.

Neo-liberal agendas in education policy have also resulted in the decentralization of responsibility for refugee and English-for-Speakers-of-Other-Languages (ESOL) programs to individual schools and educators who frequently work with inadequate funding and information. In education policy, market-driven definitions of equity commonly refer to greater consumer "choice." There is an assumed neutrality in the "free" market, which ignores the effects of social and cultural values and beliefs, the differing material conditions of people's lives, and differential access to resources including dominant knowledge and language. ${ }^{12}$ As a small, politically weak, and fragmented group, refugee "consumers" do not have greater "choice" under new market philosophy, but are in fact finding their educational options increasingly limited.

\section{Refugee Policy in New Zealand}

Since World War II, New Zealand has accepted refugees for resettlement in times of crisis. The first to be officially received as refugees were 838 Poles in 1944. Then, between 1949 and 1956, more than 6000 people, mainly from Eastern and Southern Europe, were given refuge. ${ }^{13} \mathrm{New}$ Zealand became a party to the 1951 United Nations (UN) Convention relating to the Status of Refugees in 1960 and a signatory to the following 1967 Protocol in $1973 .{ }^{14}$ War in Southeast Asia precipitated New Zealand's largest refugee influx, with more than 8000 Southeast Asian refugees having arrived in New Zealand since $1975 .{ }^{15}$ In the 1990s, the majority of refugees came from Iraq, Ethiopia, and Vietnam, with smaller numbers from Sri Lanka, Rwanda, Burundi, and Bosnia. A total of over 20,000 refugees have already been resettled in this country. ${ }^{16}$ This number may appear small in comparison to larger nations, but New Zealand ranks first equal in the world according to the number of refugees accepted per capita. ${ }^{17}$

To understand the systemic racism that exists in refugee policy, it is necessary to be aware of the wider immigration-policy framework in which it is situated. New Zealand's immigration policy has always been strongly linked with economic factors. Until 1991, immigration policy functioned largely as a labour market tool, in which approvals were determined by an "occupation priority list" that protected local interests in the labour market. ${ }^{18}$ Following the deregulation of the New Zealand economy in the 1980s, immigration began to be regarded as a means for population growth and thus expansion of the domestic market for locally produced goods and services. Since 1991, the emphasis has therefore been upon increasing the level of human capital in New Zealand with the objective of contributing to sustained economic growth. ${ }^{19}$ In line with neo-liberal ideas of a market economy, this resulted in the establishment of a "points" system and a business investor category, both of which favour highly skilled, professional immigrants, preferably with money to invest in this country and international links that will benefit New Zealand. These two new categories initially aimed to contribute to economic restructuring, but evolved into a means for economic and social development through recruitment of human capital. ${ }^{20}$

The refugee, humanitarian, and family reunification categories are technically quite separate from the points system and business investor categories, but this paper argues that the general assumption that immigrants should provide economic benefit to New Zealand has nonetheless influenced decision making about refugee cases. Thus, although immigration and refugee policy does not explicitly discriminate against any particular ethnic or social group, the ideology behind it-as well as the function and procedures involved - results in systemic racism against refugees, particularly those from non-Englishspeaking and economically poor backgrounds or countries. Policy relating to quota and asylum refugees provides a good example of the influence that the aim of "economic growth" has had on refugee policy.

\section{The "Official" Refugees: Quota and Asylum}

There are two types of "refugee" officially recognized as such by New Zealand immigration policy. The first represents individuals accepted under the refugee quota category. In 1987, a traditionally ad hoc approach to refugee selection was replaced with an annual quota of up to 800 United Nations High Commissioner for Refugees (UNHCR)-recommended refugees. ${ }^{21}$ This was reduced to 750 in 1997 when the New Zealand government had to pick up the cost of transporting refugees from UNCHR camps to New Zealand. ${ }^{22}$ Although small by international standards, the quota has rarely been fully utilized. Between 1991 and 1998, an average of only 193 people arrived under the quota each year. ${ }^{23}$ Failure to accept the entire quota is often justified by a statement emphasizing that it 
is "subject to availability of continuing community sponsorship for new arrivals." ${ }^{24}$ Thus, blame for the unfulfilled quota is implicitly placed upon the non-governmental agencies that find or provide sponsorship, rather than on government policy itself.

While the difficulties of sponsorship are real, government reluctance to fill the quota also reflects the broad aim of New Zealand's immigration policy, which is sustained economic growth. ${ }^{25}$ Consequently, governments have been reluctant to accept the full quota of refugees because they are less likely to offer New Zealand economic "returns" than other immigrants; rather, they often represent considerable "investment." ${ }^{26}$

The institutional processes that limit the number of quota refugees may be regarded as examples of systemic racism. While immigration policy is no longer explicitly discriminatory on the basis of ethnic or cultural differences, a "neutral" emphasis on economic growth has had the result of excluding many refugees, particularly those who are poorly educated, unskilled, and lacking in English language skills.

This fact is most obvious when considering the case of 400 Kosovar refugees who were readily accepted into New Zealand in 1999. Admitted under the United Nations Special Humanitarian Program, rather than the refugee quota, Kosovars with relatives in New Zealand were offered immediate permanent residence, a speedy evacuation from wartorn Kosovo, and the right of assisted repatriation. They were also the recipients of far more generous resettlement services than other refugees, including an orientation program usually reserved for quota refugees, free additional English classes, and free clothes and furniture donated by the public. ${ }^{27}$

While the urgency of the situation and media coverage encouraged such generosity, it was also precipitated by the fact that Kosovar refugees were considered far more likely to adapt quickly and provide less of an economic burden on New Zealand than their non-Kosovar counterparts. They had not spent long (if any time) in refugee camps, were generally well-educated, came from a European background, and usually spoke some English. These attributes set them apart from the majority of New Zealand refugees who come from Africa, the Middle East, and Southeast Asia. Significantly, despite their favourable socio-economic profile and the extra resettlement support, the Kosovars have still found resettlement in New Zealand a stressful and difficult experience. ${ }^{28}$

The second type of "official refugee," the asylum seeker, arrives at one of the country's borders, requests asylum, and is given "refugee status." ${ }^{29}$ A rapid increase in asylum seekers during the 1990s encouraged New Zealand governments to make it more difficult for those whom they consider "economic refugees" to get into New Zealand and to be accepted as legitimate asylum seekers. ${ }^{30}$ This move was so rapid that it caused condemnation from the UNHCR and Amnesty International. ${ }^{31}$ There have also been continuing problems with the length of time that asylum seekers have had to wait for their applications to be accepted and the conditions they have had to endure while waiting. The current Labour-Alliance coalition government has made limited investments into supporting and housing asylum seekers, ${ }^{32}$ but these issues continue to be problematic while the backlog is cleared. ${ }^{33}$ Certainly, although asylum seekers are given "refugee status" and therefore may be considered "official refugees," they are not given the same rights as quota refugees in terms of resettlement services, as outlined in the next section.

The cases of quota, asylum, and Kosovar refugees have illustrated that, even though the refugee categories were introduced on humanitarian grounds, a philosophy of economic rationalism dominates refugee policy, as it does for immigration policy and the public sector as a whole. Thus, the "neutral" goal of immigration policy — to bring economic benefit to New Zealand-has discriminatory consequences for refugees and may be considered an example of systemic racism.

\section{The "Unofficial Refugees": Humanitarian and Family Reunification}

There is additional cause to assert that there exists a state of systemic racism when taking into account the "unofficial" refugees living in New Zealand. Figures for refugees accepted into New Zealand are misleading, for considerably more refugees-according to the UNHCR definition-have arrived in this country than they suggest. Under immigration policy, only those who apply as part of the refugee quota, or who arrive in New Zealand spontaneously and are subsequently granted asylum, are considered "refugees." Others, accepted on humanitarian grounds (other than the quota) or through the family reunification program, are considered "migrants." It is preferable for the New Zealand government that refugees apply for permanent residency under general criteria, because "migrants" are not covered by the government's obligation to meet minimum standards for refugee resettlement as a signatory of the un Convention. ${ }^{34}$

This is problematic for two reasons. First, the requirements for processing "migrants"—such as numerous 
copies of documents that many refugees do not possess, a NZ\$700 application fee, and the payment of airfares-are difficult for refugees to fulfill, and place the financial burden upon refugees themselves or their relatives. ${ }^{35}$ The New Zealand government thus makes money out of these "migrants," rather than spends it transporting and accommodating them as refugees.

Second, refugee literature places considerable emphasis on the need to differentiate between refugees and other immigrants on the basis of both their immigration experience and their patterns of resettlement. ${ }^{36}$ Immigration for legitimate refugees is not voluntary; nor do they have a great deal of choice over the country in which they will begin their new life. The considerable trauma, loss, and instability that refugees have often experienced also distinguish them from other immigrants, creating a need for specific and comprehensive support to counteract such disadvantages.

By accepting refugees into New Zealand under migrant-rather than refugee-criteria, the government does not have to provide a minimum of resettlement services, as it does for quota refugees. The following discussion describes how this freedom discriminates against non-quota refugees and also highlights how, in a neo-liberal context, poorly funded non-governmental organizations (NGOS) have had to fill the gaps left in government resettlement policy.

\section{Resettlement Policy in New Zealand}

Restrictive definitions of "official" refugee numbers in refugee policy have caused further discrimination in resettlement policy. Only quota refugees are eligible for the meagre government-funded facilities available for newly arrived refugees. The New Zealand government provides quota refugees with limited, short-term aid upon arrival, based on a front-loaded model of resettlement that implicitly aims to encourage rapid economic adaptation, particularly employment. ${ }^{37}$ Such assistance includes a sixweek orientation and English language course at the Mangere Refugee Reception Center, free health screening upon arrival, and subsidization of some other health services. In addition, quota refugees are referred to the only national resettlement organization, the Refugee and Migrant Service (RMS), which the New Zealand Immigration Service (NZIS) contracts to locate and maintain community sponsors for quota refugees. ${ }^{38}$

Beyond this assistance, quota refugees-like other permanent residents - may be eligible for financial aid from the New Zealand employment and welfare agency, Work and Income New Zealand (wINZ). Such aid includes a small (NZ\$1200) Re-establishment Grant per family, possible (but recoverable) Special Needs Grants of up to NZ $\$ 800$ for accommodation, bond, or rent in advance, and likely (although not automatic) eligibility for the Emergency Unemployment Benefit after a one-month stand-down. The last is paid at the same rate as the standard Unemployment Benefit, which cannot be granted until an individual has been resident in New Zealand for two years or more.

Refugees accepted under criteria for asylum or general humanitarian and family reunification are offered no guarantees of resettlement assistance. RMS is technically not supposed to work with asylum seekers, but frequently chooses not to distinguish between this group and other refugees who are eligible to use the service. The rights of non-quota refugees to further provisions are hazy. Some receive health screening and some may be eligible for the re-establishment grant from winz. Policy states that refugees must meet the usual criteria for permanent residents to receive the NZ\$1200, but this issue is not interpreted consistently. This inconsistency is due to a lack of specific training and to office budgets that are insufficient to meet winz's legal obligation to provide interpreters when needed by refugee clients. While trials are in place to specially case-manage the employment needs of migrants and refugees, other organizational rules make it harder for easy resettlement. For example, changes to legislation in 1996 made family members of refugees joining their families in New Zealand ineligible for the re-establishment grant. ${ }^{39}$

\section{Chronic Under-Funding of Resettlement Services}

The current Labour-Alliance coalition government almost doubled funding for refugee resettlement service in Budget 2001. Yet the yearly allocation still remains limited (at NZ\$714,00o) and still favours quota refugees. ${ }^{40}$ As a consequence of the limited resettlement assistance available from central government, it is non-governmental, often voluntary, organizations that carry the load in attempting to meet refugee needs.

The NGOs do a remarkable job supporting all refugees (regardless of immigration category) in the day-to-day aspects of resettlement, rallying communities to support improvements in refugee policy and raising funds for refugee programs. ${ }^{41}$ While it has been argued that NGOS are best able to provide to assistance for refugees, ${ }^{42}$ without any comprehensive resettlement policy such services range in quality and quantity around the country. Uncertain 
funding also constrains and threatens the services offered. Even RMs is not completely funded by the New Zealand government, with the result that it and other NGOs must constantly be searching for new sources of charitable funding and must limit the services offered. ${ }^{43}$

For example, the classes available to quota refugees at the Mangere Center are the only free language tuition directly funded by the government. Thus, once even quota refugees leave the centre after six weeks, they are expected to fund their own learning. As a result, most of the noncommercial ESOL courses available around the country have long waiting lists. ${ }^{44}$ Even the two Refugees as Survivors Centers ${ }^{45}$ and $\mathrm{RMS}^{46}$ receive only partial funding from governmental sources, and it must be reapplied for each funding round. As refugees arriving in New Zealand come from increasingly disparate ethnic backgrounds, RMS is finding it more difficult to locate adequate sponsorship for them all, thus placing even greater demand on its services providing interpreters, housing, furniture, health, and education for new settlers. ${ }^{47}$ Poor funding also results in high rates of staff turnover and a reliance on volunteers, who often lack adequate training. ${ }^{48}$

It is obvious that New Zealand's first-equal ranking in the number of refugees accepted per capita masks the tendency of New Zealand governments to ignore refugees once they have arrived in New Zealand. Thus, of the ten countries that regularly resettle refugees, New Zealand rates the lowest in post-arrival support. New Zealand governments have shown little initiative in resettlement issues, tending to respond only when under public pressure, such as during the 1999 Balkan crisis. ${ }^{49}$ It can be argued, therefore, that government policy has focused on the numbers of people entering the country, rather than on how well people have settled.50

\section{Poor Coordination between Refugee Policy and Resettlement Services}

Although coordination between the agencies making policy and those implementing it has long been a problem, a neo-liberal emphasis on the decentralization of responsibility for social services, such as those provided by resettlement organizations, has made it even more difficult to achieve. While the current centre-left government is more flexible on refugee issues than previous administrations, it still has no interest in running refugee resettlement services itself, arguing that they would merely compete with those that already exist. Such an approach is considered "inefficient" under a market economy phi- losophy. ${ }^{51}$ As a consequence, no government agency has a specific or consistent policy on refugee resettlement.

NZIS thus continues to decide which and how many refugees come to resettle in this country, largely without consultation with the NGos who provide resettlement assistance. NZIS often justifies inadequacies in resettlement policy by explaining that, once refugees have entered the country, "they are no longer strictly refugees. They are now permanent residents of New Zealand." ${ }_{52}$ This implies that refugees are not considered to need any greater assistance than what is available to all permanent residents in New Zealand.

Refugees are not monitored once they have entered the country, making it difficult to assess such an assumption. The 1987 Immigration Act does accommodate an Immigrant Resettlement and Research Fund, but only recently has it been utilized in the study of migrants and refugees. ${ }^{53}$ Initial plans for a NZIs longitudinal study of migrants excluded refugees on the basis of their small numbers and difficulties in finding them. ${ }^{54}$ Now incorporating refugees, the study is still closely linked to labourmarket issues, as are pilot settlement programs in the main cities of Auckland, Wellington, and Christchurch that focus on recent business or professional migrants. ${ }^{55}$ Final results for the longitudinal survey will not be available until 2007, leaving a long delay before NZIs is likely to act on any findings..$^{56}$

Non-governmental studies have, however, long suggested that the resettlement needs of refugees are hugely neglected. Research ${ }^{57}$ has found that some refugees would prefer to return to their wartorn homelands or refugee camps in a transit country than continue the life of alienation and hopelessness that New Zealand governments have offered them. This is surely the most obvious indication that government commitments to resettlement policy have been woefully inadequate.

It could be argued that the relatively small number of refugees that New Zealand resettles each year should make the provision of a comprehensive resettlement program for refugees manageable; instead this fact is frequently used to justify inaction and minimal funding. Yet refugees who speak poor English have not adapted culturally to New Zealand and exhibit unresolved health problems; for example, they are unlikely to provide the economic "returns" that government expects. Ironically, neo-liberal market philosophies have not offered consumer choice to refugees, and ignoring the need for a government-funded, long-term program to orient refugees to New Zealand life and provide them with basic 
English-language tuition will create costs further down the line. Such a conclusion is obvious when exploring general policy arenas, where the effects of such inadequate refugee and resettlement policy commonly present themselves. In the case of education policy toward refugees and other non-English-speaking-background (NESB) school-age students, such effects continue to be ignored or underestimated, causing further systemic racism in education.

\section{Refugee and ESOL Education Policy in New Zealand}

It is clear that the inadequacies of New Zealand's refugee and resettlement policy have discriminated against refugees, particularly those who have been accepted into the country under immigration categories other than the refugee quota. Problematic in itself, that situation is worsened by a domino effect that occurs in two ways when considering education.

First, the lack of comprehensive resettlement assistance and, in particular, free English-language tuition, for refugees has resulted in a disillusioned and ill-adapted sector of society living in poverty and feeling culturally alienated. As a consequence and through little fault of their own, many refugee students are inadequately prepared for the demands and routines of educational institutions. At the same time, mainstream schools are ill-prepared to cope with refugees living in circumstances that are clearly detrimental to learning within the usual limitations of funding.

Second, policy-makers in education (and other areas of government) have followed by example. Policy for the compulsory education sector has, until very recently, separated out quota refugees for special funding, continuing to enforce "neutral" rules and procedures that discriminate against non-quota refugees. Simultaneously, compulsory education has taken on board the assumption at the basis of refugee and resettlement policy-that refugee needs are the same as those of other migrants. This failure to adequately identify refugee-specific needs has resulted in educators' failing to meet the challenge that refugee students represent, thus contradicting policy statements espousing inclusiveness of and engagement with diversity.

Once again, these inadequacies sit within a context of neo-liberal decentralization of the public sector and state movement towards a market economy. Students have gone from being citizens with rights to a fair education to consumers of a product. In addition, the traditional notion of "equity" has been linked to "choice" for the con- sumer, without the realization that accommodating the needs of diversity and commodifying education are contradictory. ${ }^{58}$ Confusion in policy documents about "equality" and "equity" has left educators stranded when attempting to find how to best meet the differential needs of refugee students.

\section{Refugee Students in New Zealand Schools}

School-age refugees, on whom this discussion of education policy concentrates, have often experienced gaps in schooling. Once living in their new host society, many receive insufficient educational support at home because their parents do not speak the host country language or are poorly educated themselves. In addition, school-age refugees have frequently experienced trauma, and their cultural background is usually vastly different from that of the society in which they now live. School-age refugees, like their older counterparts, also tend to experience considerable poverty. All of these factors stem from the refugee and resettlement experiences and can have effects on the educational adaptation of refugee students, although obviously the success of their adaptation varies between groups and individuals, depending on their ethnic, religious, linguistic, and previous socio-economic background.

During the 1980s when large influxes of refugees from Southeast Asia began to arrive in New Zealand, some educators realized that refugees were exhibiting differential needs in comparison to general migrant students. As a result, the Department (now Ministry) of Education introduced a scheme by which one secondary school in each of four New Zealand cities was funded to act as a "reception" class for new refugee students. There they could learn English within their own ethnic group before moving into the regular school system. ${ }^{59}$ This funding continues, but only when there are a large number of refugees from one ethnic group arriving in a city at the same time.

As a result, most refugee students now end up in the ESOL program of a mainstream school almost immediately upon arrival. In Auckland, the city in which the majority of refugees reside, refugee students are placed within mainstream classes and withdrawn from class for ESOL assistance and provided with a trained and funded "mentor" to help with homework and academic issues. Over the last few years, the Ministry of Education has also developed a National Esol team, which includes a national refugee coordinator and four regional refugee education coordinators. Six regional school advisors for new 
settlers and multicultural education also assist in-service teachers of refugees and migrants with professional development, visit schools, and help to establish EsOL programs. $^{60}$

Despite such assistance, general Esol programs and mainstream classes seldom provide refugee students with instruction in the basic practices of learning and teaching utilized in New Zealand education. An example from the experience of Somali students, many of whom have little or no socialization in education even in their own country, suggests that this neglect is highly problematic. Basic tasks such as getting to class on time, maintaining lesson notes in an orderly fashion for examination revision, or working cooperatively within a group are unfamiliar practices for students with little or no education. ${ }^{61}$

Even refugee students lucky enough to have experienced prior education find the pedagogical and cultural differences of New Zealand schools difficult to cope with. For instance, New Zealand prefers teaching methods that encourage independent learning patterns, lateral thinking, problem solving, and group work. Such emphasis contrasts with the more stratified approach prioritized in many countries, in which learning relies on memorization and recitation. Difficulties in learning new conceptual knowledge are exacerbated by a lack of books and teaching material suitable for refugee students. These are just a few of the difficulties that refugee students must face at school, while the inadequacies of resettlement policy ensure that the majority of their parents become increasingly disillusioned with the impoverishment and marginalization they have found in New Zealand.

\section{Refugee and ESOL Student Funding}

In trying to cope with the effects that poor resettlement policy has had on refugees, education policy for the compulsory education sector has made some progress in identifying the needs of refugee students. But until very recently, such progress has been limited by a favouring of quota refugees similar to that found in refugee and resettlement policy. In 1998 the Ministry of Education implemented a new funding system for ESOL, which provided more support for ESOL students than ever before, but implemented a supplementary grant that recognized only quota refugees. Funding was also very limited, with quota refugees entitled only to a one-off grant of NZ\$500 per student paid to schools rather than refugee families. This one-year-only funding made a mockery of research demonstrating how long it takes to learn a language, and resulted in only 158 individuals, out of 21,619 students funded under the NESB criteria across the country, being eligible for the quota refugee grant. ${ }^{62}$

In July 2000, however, after considerable pressure from refugee and education advocates - and a change in central government - this funding was improved. All refugee students with UNCHR documentation are now eligible for a NZ\$1100 (NZ\$1700 in secondary schools) per year for their first two years of study, and NZ\$500 for the three years following. This funding is guaranteed as long as their English Assessment Score remains below a certain point on the National Esol scale. Such recognition of the needs and rights of non-quota refugees had resulted in 1534 refugees being funded as such in 2000 , a considerable jump from the 158 of $1998 .{ }^{63}$

The change in funding suggests that, when identified, systemic racism may be overcome, even if in only a single policy area. Yet while educators have welcomed the extra funding, it still makes only a dent in the cost of addressing refugee needs, particularly in schools with only a small number of refugees. In addition, the esol funding provided by the Ministry “doesn't remotely begin to cover" the real costs of running an ESOL program, and most schools consequently do not regard the Ministry as a reliable source of long-term funding for an EsOL program, but rather as "a bit extra." Thus the change in funding has clearly not eliminated the systemic bias against refugees that stem from poor resources and assumptions that they share the same needs as other migrant students.

\section{Responsibility for Refugee Education}

Since the neo-liberal reforms that transformed the New Zealand public sector in the 1980s, the problem of inadequate funding for refugee and ESOL students has increasingly become the responsibility of the educators and administrators of individual schools. When funding is generated by a set amount of money given per NESB student on the roll and it is inadequate to cover the actual costs of running an Esol program, school principals and boards of trustees are having to make tough, discretionary decisions. According to the neo-liberal model, they have a "choice" about whether to continue supporting an ESOL program by using general funds, possibly at the expense of other areas of the school, or to discontinue running an ESOL program.

Most schools have discovered that there is no real choice, for rising numbers of NESB students each year make an Esol program a necessity. Some schools are actively marketing themselves to foreign students to cover the costs of ESOL, but O'Connor ${ }^{64}$ suggests that this has 
resulted in an English-as-a-Foreign-Language approach to teaching, which does not necessarily meet the ESOL needs of refugee and immigrant students resident in New Zealand.

Just as NGOs have been saddled with the cost of helping refugees to settle in New Zealand, schools have had to stretch their general budgets to cover the costs of Esol, particularly for the extra programs that refugee students have required. Some have discouraged refugees from attending their school because of the cost and effort needed. Thus, a neo-liberal philosophy reputed to bring about greater educational responsiveness to community needs has precipitated the exit of some schools from the education of refugees. If refugee needs were being met elsewhere, this would not be a problem. But instead, refugee students are increasingly being forced into mainstream classes in which they cannot cope and whose teachers are not trained in dealing with Esol students, let alone those who are refugees.

Some schools have made attempts to bridge this gap in knowledge, but they struggle against the systemic racism found in the education system that favours the mainstreaming of all special-need or disadvantaged groups. In a Christchurch study of Somali secondaryschool students, ${ }^{65}$ most mainstream schools visited had provided segregated classes and/or subject-specific support in class for Somali and other refugee students so that they were able to receive more individualized attention. Yet such measures were implemented only when a large number of Somali students enrolled at once-forcing schools to acknowledge their presence-and lasted only a short time. In addition, these forms of educational initiative focused on transmission-giving Somali students enough "knowledge" to embed them within dominant culture-rather than on transformation of the system. ${ }^{66}$

\section{Lack of Information and Policy Guidance}

The hesitance with which schools offer refugee-specific classes is partly due to a lack of information. Material accompanying the ESOL funding procedure does provide basic facts about refugee students, the general educational status of various refugee ethnic groups found in New Zealand, and brief suggestions on how to support refugee children in schools. ${ }^{67}$ However, more often than not, refugee students have not been identified as a specific group at all.

Refugees are most often encompassed within the very broad grouping of NESB students. This group includes those who are new to New Zealand and have had no pre- vious exposure to the English language or schooling, along with students who have been in the New Zealand education system for some time but have difficulty with English language in the mainstream. The needs of such a wide range of students are clearly difficult to assess and provide for ${ }^{68}$ Recognition of refugee needs has thus been ad hoc and focused solely on the language requirements of such students, while ignoring the process of adaptation through which they must travel.

Poor information has resulted in some educators blaming the lack of conceptual understanding of refugee students on a lack of effort, rather than on cultural or pedagogical differences. As a consequence, the systemic racism that began with insufficient resettlement services for refugees has been translated into school inadequacies that cause some educators to regard refugee students as "lazy" or "troublesome," rather than representing differential needs.

In addition, educators demonstrate ambiguity when offering differential support for the students. Christchurch teachers of Somali, for example, admit that refugee-specific classes appear to have helped Somali students, but emphasize the need for them to be treated "equally" (that is, the same as other non-immigrant students) as soon as possible. Despite a shift away from "equality as sameness" and towards "equity as diversity" within educational policy since 1975, attitudes have not necessarily changed. Rather, the beliefs of many Christchurch teachers appear to be squarely rooted in notions of equality of opportunity.

The lack of information available to teachers has been exacerbated by a competitive market-oriented educational environment, which discourages collaboration and sharing of materials. ${ }^{69}$ Without an ESOL curriculum across all educational sectors or a consistent assessment regime for ESOL students, teachers are constantly "reinventing the wheel." According to Glynn, Pongudom, and McMillan, ${ }^{70}$ New Zealand teachers lack the level of professional advice and guidance from colleagues skilled in such techniques available to their counterparts in Australia, Britain, and the United States. This is particularly so in the case of refugee students.

In addition, the dominance of neo-liberal understandings of "equity" has provided confusion and ambiguity in education policy. For example, the frequent conflation of individual free choice (unencumbered by state bureaucracy) and individual and community "empowerment" (with state assistance) is problematic, ${ }^{71}$ because in the case of refugees there is little evidence of empowerment. 
Neo-liberalism has taken traditional liberal pluralist values to the extreme. Such values tacitly assume that what we have in common and what we do or accomplish as individuals is more important that what divides or separates as members of a group..$^{72}$

Such a commitment to universalism and formal equality is empowering where there is a "level playing field." But it is problematic when group-based differences need to be taken into account as a basis for entitlement to attaining true equality and full participation. ${ }^{73}$ Education policy in New Zealand fails to clarify the concepts of "equality" and "equity," with the result that educators are employed to interpret and implement policies for which they are unprepared financially, practically, and ideologically.

\section{Conclusion}

Examination of refugee, resettlement, and education policy provides examples of the systemic racism that exists within New Zealand institutions and discriminates against refugees. Through the application of supposedly "neutral" goals, rules, procedures, and categories, immigration and education institutions have differentiated between quota and other refugees, while simultaneously arguing that refugees should not be treated differently from general migrants. This ambiguity has influenced and is reflected in other policy areas, as the case of the compulsory-education sector has demonstrated. New Zealand has signed a un convention protecting the rights of refugees through the immigration process and resettlement. The Ministry of Education's ${ }^{74}$ National Education Guidelines state that students with "special needs" should be identified, and teaching and learning strategies should be developed and implemented to address them. In both cases, refugee rights remain to be fully recognized and addressed.

For years now, refugees, NGOs involved in resettlement, and educators working with refugee students have called for a centrally funded and integrated refugee resettlement program, which is regarded as the logical outcome of the commitment by the government of New Zealand to the un convention. Such a program would redefine relatives of those accepted under quota as people equivalent to refugees, would provide adequate resettlement support for all refugees, and would send appropriate messages to policy-makers in all sectors, including education, that the specific rights and needs of refugees must be fully addressed. ${ }^{75}$ Yet no New Zealand government has been willing to fulfill this commitment.
Cases of blatant systematic racism are harder to find in New Zealand's institutions since the articulation of bicultural and multicultural agendas and a greater focus on human rights legislation. The subtle and often unconscious and unintended nature of systemic racism, however, makes it more difficult to eradicate. This is particularly so in a country where New Zealanders frequently pride themselves on the egalitarian "colourblind" rules and "universal" standards that nonetheless discriminate against refugees. In addition, neo-liberal agendas have enhanced the adverse effects of such systemic racism. Yet the policy-makers in education have finally listened to calls for EsOL funding that does not discriminate against non-quota refugees. Their attentiveness demonstrates the need for greater awareness of refugee issues and suggests that sufficient pressure could force New Zealand governments not just to "count the numbers," but to ensure that life for refugees in resettlement is better than it was in the world they left behind.

\section{Notes}

1. See Louise Humpage, "Refuge or Turmoil? Somali Adolescent Refugees in Christchurch Schools: Intercultural Struggle and the Practices of Exclusion" (M.A. thesis, University of Canterbury, 1998). The examples used from this research will not be further referenced.

2. Augie Fleras and Jean Leonard Elliott, Unequal Relations: An Introduction to Race, Ethnic and Aboriginal Dynamics in Canada, 3rd ed. (Scarborough, on: Prentice-Hall Canada, 1999), 68-9.

3. Ibid., 82-3.

4. Paul Spoonley, Racism and Ethnicity, 2nd ed. (Auckland: Oxford University Press, 1995), 22.

5. Fleras and Elliott, Unequal Relations, 82.

6. Arvind Zodgekar, Immigrants in New Zealand Society (Wellington: Victoria University Press, 1997), 13.

7. Statistics New Zealand, New Zealand Official Yearbook, 2000 (Wellington: GP Publications, 2000), 211.

8. Fleras and Elliott, Unequal Relations, 81-3.

9. In 1984 the Fourth Labour Government came to power and began a radical restructuring of the public sector, which corporatized and then privatized many public assets and services. At the same time, the New Zealand economy was heavily deregulated. Such neo-liberal policies were continued under National Party-led governments throughout the 1990s, rapidly transforming the New Zealand public sector and society.

10. This was the Labour-Alliance coalition government. The introduction of neo-liberal reform under the Fourth Labour Government went against the centre-left ideology traditionally associated with the Labour Party. The Labour-Alliance coalition represents an (incomplete) move back towards these centre-left origins. It is important to point out that all 
references to government refer to central government structures at the national level.

11. Zodgekar, Immigrants in New Zealand Society, 13.

12. Alison Jones, Gary McCulloch, Linda Tuhiwai Smith, et al., Myths and Realities: Schooling in New Zealand, 2nd ed. (Palmerston North: Dunmore, 1995), 122-3.

13. Tom Brooking and Roberto Rabel, "Neither British Nor Polynesian: A Brief History of New Zealand's Other Immigrants," Immigration and National Identity in New Zealand, ed. S. Greif (Palmerston North: Dunmore, 1995), 23-49.

14. Reg Palmer-Ororwujea, "Refugee Migration: Theory and Experience," Refugee Resettlement and Wellbeing, ed. M. Abbott (Auckland: The Mental Health Foundation of New Zealand, 1989), 131-43.

15. Brooking and Rabel, "Neither British Nor Polynesian," 44.

16. Statistics New Zealand, Official Yearbook, 200o, 132-4. This vague figure has circulated for many years, but a more accurate statistic is not available.

17. Patrick O'Connor, "Migrants and Refugees: A Christian Response?" The Common Good: Taking a Preferential Option for the Poor: A Newspaper of the Christchurch Catholic Worker 9 (spring 1998), 4-5.

18. Zodgekar, Immigrants in New Zealand Society, 10.

19. Richard Bedford, Joanne Goodwin, Elsie Ho, et al., Regulating International Migration: A New Zealand Perspective (Auckland: Asia-Pacific Migration Research Network/Massey University, 1998), 5.

20. Andrew Trlin, Anne Henderson, Nicola North, et al., "Immigration, Human Capital and Productive Diversity: Contrasts and Issues in the Employment Experiences of New Settlers from China, India and South Africa" (paper presented at Vibrant Voices and Visions for Ethnic New Zealand conference, Auckland, March 9-11, 2001), 2.

21. Ministry of Foreign Affairs and Trade, Ministerial Press Release, online: Ministry of Foreign and Trade <http:// www.mft.govt.nz/Guide/part4.htmlı\#4.3> (date accessed: 17 April 1998).

22. Max Bradford, Ministerial Press Release, online: New Zealand Executive Government <http://www.executive.govt.nz/minister/ bradford/mbno107.htm> (date accessed: 13 June 1997).

23. This statistic was gained by adding figures found in Alexander Trapeznik, "Recent European Migration to New Zealand," Immigration and National Identity in New Zealand, ed. S. Greif (Palmerston North: Dunmore, 1995), 77-96, and New Zealand Immigration Service, Applications, People and Ratio of Approvals for Residents by Category by Calendar Year for 1992-1998, online: New Zealand Immigration Service <http://www.immigration.govt.nz/research_and_ information/statistics/> (date accessed: 6 June 2001).

24. New Zealand Working Party on Immigration, Report of the Working Party on Immigration (Wellington: New Zealand Working Party on Immigration, 1991), 3.

25. Patrick Ongley, "Immigration, Employment and Ethnic Relations," Nga Patai: Racism and Ethnic Relations in Aotearoal New Zealand, ed. P. Spoonley, D. Pearson, and C. Macpherson (Palmerston North: Dunmore, 1996), 13-34.
26. Stuart Greif, "Introduction," Immigration and National Identity in New Zealand, ed. S. Greif (Palmerston North: Dunmore, 1995), 7-20.

27. Heather Devere, Teuta Kajitazi, Man Hau Live, et al., "Kosovars in New Zealand: A Special Case of Refugee Resettlement" (paper presented at the Sociological Association of Aotearoa (NZ) conference, Hamilton, November 17-19, 2000), 1-2.

28. Ibid., 4, 10 .

29. Kath Jamieson and Michael Peters, "Report on Refugee Issues in Christchurch" (Christchurch: Leisure and Community Services Unit, Christchurch City Council, 1997), 10.

30. Lloyd Jones, "The Refugee Door Is Slightly Ajar," New Zealand Herald, 29 August 1992.

31. Pat Baskett, "New Life Buys New Struggles," New Zealand Herald, 28 July 1995.

32. Lianne Dalziel, "Address to Christchurch Refugee and Migrant Forum" (Christchurch, 21 July 2000), 6.

33. Interdepartmental Committee, Refugee Resettlement: Actions Expected and Progress to Date, discussion document at Interdepartmental Committee meeting (Christchurch, 19 October 1998), 15.

34. Jamieson and Peters, Report on Refugee Issues, 10-11.

35. Kathryn Brightwell, "Sponsorship and Refugee Resettlement: The Somali Experience" (M.A. thesis, University of Waikato, 1996), 66.

36. For example, Barry Stein, "The Experience of Being a Refugee: Insights from the Research Literature," Refugee Mental Health in Resettlement Countries, ed. C. Williams and J. Westermeyer (New York: Hemisphere Publishing, 1986), 5-21; San Duy Nguyen, "Towards a Successful Resettlement of Refugees," Refugee Resettlement and Wellbeing, ed. M. Abbott (Auckland: The Mental Health Foundation of New Zealand, 1989), 71-86; Ruben Rumbaut, "Migration, Adaptation and Mental Health: The Experience of Southeast Asian Refugees in the United States," Refugee Policy: Canada and the United States, ed. H. Adelman (Toronto: York Lanes Press, 1991), 381424.

37. Michael Lanphier, "Refugee Resettlement: Models in Action," International Migration Review 17, no. 1 (1983), 4-33.

38. Statistics New Zealand, Official Yearbook, 200o, 134.

39. Interdepartmental Committee, Refugee Resettlement, 13.

40. Lianne Dalziel, "Refugee Resettlement Services Funding Boost," online: New Zealand Executive Government $<$ http:// www.executive.govt.nz/budget2001/people-refugees.htm > (date accessed: 28 May 2001). The New Zealand Immigration Service has plans to establish a resettlement unit that will target "migrants": a category said to include refugees. It is unclear at this stage if it will include non-quota refugees.

41. Fran Wilde, "Speech of Welcome to Dr. Haing Ngor," New Settlers and Multicultural Education Issues 7, no. 2 (1990), 8-9.

42. See Simon Field, Resettling Refugees: The Lessons of Research, Home Office Research Study 87 (London: Her Majesty's Stationery Office, 1985), 12-13; Brightwell, "Sponsorship and Refugee Resettlement," 24.

43. Statistics New Zealand, Official Yearbook, 2000, 134. 
44. Patrick O'Connor, ESOL Provision: South Island 1998 (preparatory notes for Briefing Paper to the Interdepartmental Committee on Refugees, Christchurch, September 1998), 3.

45. Lucy D'Aeth, "Briefing Paper to the Interdepartmental Committee on Refugees" (presented to the Tripartite Consultation on Refugees Meeting, Auckland, 7 October 1998), 1.

46. Statistics New Zealand, New Zealand Official Yearbook, 1997 (Wellington: GP Publications, 1997), 150.

47. Brightwell, "Sponsorship and Refugee Resettlement," 83.

48. Ibid., 28.

49. O'Connor, ESOL Provision, 3-4.

50. Dalziel, "Address," 3.

51. Ibid., 4.

52. Department of Labour, Refugees: Twenty-Five Questions and Answers, Leaflet No. 23, New Zealand Immigration Division (Wellington: Department of Labour, 1986), 6.

53. New Zealand Government, "Immigration Act 1987 as Reprinted 1995: Section 149a: Immigration Resettlement and Research Fund," Reprinted Statutes of New Zealand with Amendments, 33 (Wellington: New Zealand Government, 1995), 328.

54. New Zealand Immigration Service, Background Information: Longitudinal Immigration Survey: New Zealand (Wellington: New Zealand Immigration Service, 1999), 2.

55. Dalziel, "Address," 5.

56. New Zealand Immigration Service, Background Information, 2.

57. For example, Humpage, "Refuge or Turmoil?" 28; O'Connor, The Common Good, 4.

58. See Jan McPherson, "Approaching Equity through School Language Policy" (M.A. thesis, Palmerston North, Massey University, 1991), 25; Joe Kincheloe, Toil and Trouble: Good Work, Smart Workers, and the Integration of Academic and Vocational Education (New York: Peter Lang Publishers, 1995), 17.

59. Wiremu Kaa, "The Department of Education," Refugee Resettlement and Wellbeing, ed. M. Abbott (Auckland: The Mental Health Foundation of New Zealand, 1989), 245-6.

60. Anne Lee, personal communication, 29 May 2001.

61. Nola Cochrane, Anne Lee, and Pamela Lees, "Refugee Students with No Previous Schooling," Many Voices: Journal of New Settlers and Multicultural Education Issues 5 (May 1993), 18-19.

62. Ministry of Education, Improving Achievement of Students at Risk of Educational Failure: Secondary School System to Cater for Students at Risk of Educational Failure, online: Ministry of Education <http://www.minedu.govt.nz/schools/improving achievement $>$ (date accessed 17 April 1998).

63. Lee, personal communication.

64. O'Connor, ESOL Provision, 7.

65. Humpage, "Refuge or Turmoil?"

66. Albert Wendt, "An Education System for Whom?" (keynote address at the National Forum on Pacific Island Education in New Zealand, Auckland, Nga Tapuwae College, 1985), 14.

67. Ministry of Education, "C: Assessing Students/Information on Refugee Students," Non-English Background Students in New Zealand Schools: ESOL Resourcing Information (Wellington: Ministry of Education, 1997), 1-12.
68. Shelley Kennedy and Sharon Dewar, "Non-English-Speaking Background Students: A Study of Programmes and Support in New Zealand Schools" (Wellington: Research and International Section, Ministry of Education, 1997), 36.

69. Judi Altinkaya, "Briefing Paper to the Interdepartmental Committee on Refugees: Access to English Language Support" (presented to the Tripartite Consultation on Refugees Meeting, Auckland, 7 October 1998), 2.

70. Ted Glynn, Wilai Pongudom, and Bruce McMillan, "Responsive Feedback for Four Bilingual Learners Writing Stories on Computers," New Settlers and Multicultural Education Issues 7, no. 3 (1990), 43-51.

71. Jones et al., Myths and Realities, 132.

72. Augie Fleras, "Communicating Together with Our Differences," Police, Race and Ethnicity: A Guide for Law Enforcement Officers, eds. B. Cryderman, C. O’Toole, and A. Fleras, 3rd ed. (Toronto: Butterworths, 1998), 59-85.

73. Louise Humpage and Augie Fleras, "Systemic Bias and the Marginalisation of Somali Refugee Adolescents within New Zealand Education," New Zealand Sociology 15, 1 (2000): 46-74.

74. Ministry of Education, Minister of Education: A Report on the Compulsory School Sector (Wellington: Ministry of Education, 1999), 23.

75. Jamieson and Peters, Report on Refugee Issues, 7.

Louise Humpage is a doctoral candidate at Massey University, Albany, New Zealand. Although her research is now in Maori Affairs policy, she maintains the keen interest in refugee and migrant issues that she developed while completing her master's degree, which explored the experiences of Somali adolescent refugees resettling in New Zealand. 